\title{
TRAINING INTRODUCTION AND CONTROLLING HYDROPONIC PLANTS
}

\author{
Arissetyanto Nugroho \\ Universitas Mercu Buana Jakarta, Indonesia.
}

\begin{abstract}
This training is an activity related to the economic empowerment of the community through the development of vegetable cultivation using the hydroponic planting method. The problem that arises in the development of vegetable plants is the presence of plant pests that cause the growth of vegetables to be slow or even damaged before the harvest. To support the economic empowerment efforts of the extension community and training on the use of hydroponic farming through residents residing in Anggadita village. For this reason, this activity will be given assistance and training in hydroponic plant cultivation skills, so that in the future the community will be able to become an example in the cultivation of hydroponic vegetable plants, this will at least help reduce the economic burden on the family, especially for the fulfillment of healthy vegetables. The expected outcome of this activity is the development of knowledge on how to grow hydroponics in Anggadita village and the formation of a hydroponic care social group that can increase the awareness of community members in the cultivation of hydroponic plants.
\end{abstract}

Keywords: Plant Pests, Hydroponic Systems, Economic Improvement, Social Groups

\section{INTRODUCTION}

The Bekasi region as one of the buffer cities in Indonesia is a highly populated industrial city. High population density with an area that does not have a balance because the area gradually decreases due to abrasion.

The function of green open space in the pace of city development is often constrained by economic interests. Green open space has an important role not only in the environmental and aesthetic dimensions of the city but also in social and cultural dimensions. The public hopes for greening in their area.

At present, urban growth is directly proportional to the increase in population. Consequently, the construction of urban facilities and infrastructure has increased. Land requirements for development continue to increase. As a result, green areas in strategic locations are often threatened by their economic value.

The area of green open space in Bekasi is currently around 75 square kilometers or only 9.8 percent of the City's total land area. This figure is still far from the minimum limit of 30 percent as stipulated in Law Number 26 in 2007 concerning Spatial Planning. The development of urban spatial planning has shifted more the function of green open space to commercial and office areas.

Observe and compare the 2005 RUTR, Regional Spatial Plan (RTRW) number 2010, and number 2030, the existence of deviations of land functions in the City. Spatial development for the period 2005-2010 has degraded the extent of green open space. Nearly $20 \%$ of the existing green open space is turned into an economic zone.

The biggest deviations in land use occur in industrial estates. The green area in Bekasi is reduced by $34 \%$ and outside the industrial area is reduced by $25 \%$. Meanwhile, changes in the function of the area in residential areas are more concentrated on land-use change. No less than $60 \%$ of residential areas in Bekasi occur around commercial and office areas.

Greening activities are part of agricultural activities. It is known that agriculture is one of the fields that require quite a lot of water. In the context of greening and efforts to minimize water needs, the hydroponic system is one of the choices that can be taken.

Greening activities are part of agricultural activities. It is known that agriculture is one of the fields that require quite a lot of water. In the context of greening and efforts to minimize water needs, the hydroponic system is one of the choices that can be taken.

Hydroponics is the cultivation of planting by utilizing water without using soil by emphasizing the fulfillment of nutritional needs for plants. Water requirements in hydroponics are less than water requirements in aquaculture 
with soils. Hydroponics uses water more efficiently, so it is suitable to be applied in areas that have a limited water supply.

Greening with hydroponic farming needs to be socialized to the wider community. Hydroponically planting can also save the household budget because the crops planted can be vegetables consumed daily.

Greening by planting in a hydroponic system needs to be socialized to the wider community. Hydroponically planting can also save the household budget because the crops planted can be vegetables consumed daily.

For this reason, it is necessary to conduct socialization on eradicating pests of hydroponic plants to mothers on RT 22 in the village of Anggadita.

The material that will be presented at the community service activities is knowledge about pests that often attack hydroponic plants, and how to control these pests.

\section{TARGET OUTCOME}

The target of these community service activities is to increase community knowledge and skills in greening the region. Reforestation is done by planting hydroponically for vegetable crops. If the community already has the knowledge and skills regarding planting in a hydroponic system, especially for vegetable crops, it is expected that the environment will be greener and more beautiful. Each house can create a "living area" which can also be useful to save household expenses. Besides, hydroponic cultivation saves water usage and produces healthier plants for consumption.

The expected outcome of this community service activity is to increase the community's knowledge and capability in hydroponic farming. Evaluation of the results of service activities is done by comparing the knowledge of participants before and after the implementation of activities. The evaluation mechanism is to share questions before and after service activities. The answer to the question is tested whether there is a difference between the answers before counseling and after counseling.

\section{METHODOLOGY}

The method of community service activities is counseling or training. Participants in the activities followed the explanation of the speakers so that the participant's knowledge of how to recognize and eradicate pests of hydroponic plants increased. Hydroponic plants are known as high-quality plants, compared to plants grown conventionally by planting them in the soil. The high quality is also caused by hydroponic plants if they are attacked by pests with non-chemical eradication.

There are various ways or recipes for making organic pesticides. Until now there is no standardization of making organic pesticides. Organic pesticide recipes are usually obtained from the experience of farmers, local wisdom of the community, the results of the experiments of practitioners and based on scientific research. Here are some ways to make organic pesticides that are often used by farmers to control pests.

\section{a. Insect control (ladybugs and fleas)}

Ingredients: $1 \mathrm{~kg}$ Surian leaf, $1 \mathrm{~kg}$ tobacco leaf, $1 \mathrm{~kg}$ lagundi leaf, $1 \mathrm{~kg}$ titonia leaf, 2 liter coconut water, 0.5 ounce gambier, 1 ounce salt and $500 \mathrm{ml}$ hot water. Tool: masonizer.

How to make: mash tobacco leaves, surian leaves, lagundi leaves, and titania leaves, stir until smooth. When it's soft, soak it in coconut water and stir. Then extract the mixture by squeezing it with a cloth. Refine the juice and add salt and stir the solution. Prepare the gambier liquid by dissolving half an ounce of gambier in $500 \mathrm{ml}$ of hot water, then strain it with a soft cloth. The final step is to mix the leaf solution and gambier solution. Put it in a bottle or plastic jerry can. Organic pesticide ingredients ready to use.

How to use this organic pesticide is to dilute $500 \mathrm{ml}$ of solution in 10 liters of clean water. Mix well and put in a spray tank. Spray the top of the plant first and then the top and bottom surfaces of the leaves. The frequency of spraying is recommended twice a week until the larval or flea populations are reduced and no longer harmful.

\section{b. Leaf-eating caterpillar controller}

Ingredients: 2 liters of coconut water, 1-grain yeast tape, 4 ounces of garlic, 0.5 ounces of detergent and 4 ounces of lime. The first step is to mash the garlic until smooth. Then dissolve the detergent into coconut water and stir until evenly distributed. After that, add the garlic mash, yeast tape, and lime. Strain the mixture with a soft cloth. The final step, ferment the liquid for 20 days in a closed container. Organic pesticides repellent leaves caterpillars are ready to use.

How to use: dilute $500 \mathrm{ml}$ organic pesticide solution with 10 liters of clean water. Mix well and put in a spray tank. Frequency of use 2 times a week. Continue to spray until the caterpillar attack decreases to a safe level. 


\section{c. Insect control, ladybugs and ticks from Inggu leaves}

Ingredients: $1.5 \mathrm{~kg}$ of leaves, $1.5 \mathrm{~kg}$ of chicken droppings, 0.5 ounces of gambier, 3 liters of coconut water and $500 \mathrm{ml}$ of hot water.

How to make: Inggu sunday leaves and chicken manure pounded until smooth and soak in coconut water. Squeeze and strain the mixture. Then prepare the gambier solution with hot water that has been filtered. Mix the two solutions. Pinggu leaves organic pesticides are ready to use.

How to use: 1 liter of organic pesticides diluted with 10 liters of clean water. Mix well and put in a spray tank. Spray all parts of the plant, spraying frequency twice a week.

\section{d. Ant and Flea Control}

Pests that also often attack hydroponic plants are ants and fleas. Ants are social creatures and live in large colonies that have a specific division of tasks. In essence, ants are not too disturbing if the numbers are small. It can even help pollinate flowers to become fruit. However, what ants will become pests if the numbers are very large and cause white lice to appear and plant growth will be disrupted.

Step to overcome the pest ants on plants :

1. Baking soda is toxic to ants, sprinkle around the plants to make sure the ants will stay away.

2. Flour and Baby Powder will keep ants away from the plant.

3. Can use coffee grounds, chili powder, cinnamon, peppermint or black pepper. All of these ingredients prevent ants, and if the coffee powder is directly poured into the anthill, they will eat the coffee grounds and explode.

4. Grits, instant rice and wheat cream can be sprinkled around the plant. Ants will eat a piece where the sprinkle is and kills the ant.

5. Fill the spray bottle with vinegar and water then spray it on the plant. Acid in vinegar will kill ants.

6. Mix molasses, six tablespoons of sugar, and six tablespoons of active dry yeast into a fine paste. Use the mixture to strip the cardboard coat. Keep out of the reach of pets and small children. Leave the mixture on a plate outside the anthill and they will eat it and die.

7. Fold the paper in half, sticking out and making a circle around the base of the plant. Ants stuck on paper problem solved.

8. Cut the bottom of the paper cup and cut the gap over the side of the cup and outer coat with vasseline and place around the base of the plant. You can also use packing tape.

9. Mix one cup of borax, two-thirds cup of sugar, and one cup of water. Dip a cotton ball in the liquid and place it in an area near the anthill. Your ant will leave only the plant and swallow the sweet mixture. Borax kills ants.

10. Diatomaceous Bumi is an organic pesticide usually used to destroy insects, and cause pests to die from dehydration.

Before counseling or training begins, participants are given several questions as a Pre-test. Questions are presented in the form of closed questions. After the end of the counseling activity the participants were again given several questions as a Post-test, also in the form of closed questions. It is expected that there will be differences in participants' knowledge about the types of pests and diseases that often attack hydroponic plants and how to control or eradicate them.

\section{RESULT}

This activity was held in the context of routine community service activities as one of the Tri Darma University. This activity is well organized and on time. The number of participants attended was 15 people.

Training materials were distributed to participants regarding theoretical and practical material. The training material is presented in the form of power points as well as hydroponic plant pest cases. The training material is explained interactively in the form of class presentations and discussions. The introduction of hydroponic plant pests is discussed in groups.

This community service is carried out utilizing field surveys, interviews, and hands-on practice. Based on the results of interviews with several residents, they need training in introducing hydroponic plant pests to increase knowledge and technical skills to obtain the ability to cultivate hydroponic plants.

Related to the identification of the problem being discussed, the discussion of the problem is:

1. Provide understanding and knowledge about the introduction of hydroponic plant pests to create a prosperous society.

2. Providing training and technical skills to the public regarding hydroponic plant pests.

3. Provide a simulation introduction to the types of pests of hydroponic plants. 
This activity was evaluated in several ways, with 15 registrants. The presentation of training materials is carried out according to the training schedule. From the recapitulation results of the training evaluation sheet, it was found that the participants stated that the training was very useful to increase understanding related to the effectiveness of interpersonal communication in the introduction of hydroponic plant pests.

Factors that make the activity successful:

a. Good communication between the training teams and participants.

b. Good collaboration between the team and training participants.

c. The enthusiasm of the participants when attending the training.

While the factors that become obstacles are:

a. Guidance and training cannot only be done in one day because quite some participants do not yet know the types of pests in the cultivation of hydroponic plants.

b. Limited eveny budget.

\section{CONCLUSION}

The results of the discussion of the entire set of training activities above, can be concluded as follows:

Overall, the training participants are dominated by individuals who have a creative spirit. Participants can express their ideas and opinions but need time to adjust well in the training situation. The participant's thinking patterns are quite open-minded and flexible.

a. The class atmosphere is quite lively and 'alive'. Participants are creative and tend to express their opinions openly, both in group discussions and individually.

b. Overall, the participants said the training activities were interesting, many 'new' things were obtained and learned during the activity. The training material is very useful for participants to better understand about hydroponic plant pests.

c. This activity can be used as a means of communication, friendship and socialization of the Masters Program in Management at Mercu Buana University to the community, as well as a manifestation of the social responsibility of the Higher Education Institution - Tri Darma University.

From the conclusions above, there need to be continuous improvements to get the expected results by resolving existing obstacles. The advice that needs to be followed up is that the duration of the implementation of training activities can be extended to two days. Within two days of the activity, it is expected that material and practices related to the introduction of hydroponic plant pests so that they can understand the types of plant pest controllers that are suitable to their needs and environmental conditions can be delivered more optimally.

\section{REFERENCES}

http://www.indofishclub.com/t2401-cara-pengendalian-hama-pada-tanaman-hidroponik (diunduh 10 April 2017) http://alamtani.com/pestisida-organik.html (diunduh pada 10 April 2017)

http://budidayahidroponik.blogspot.coid/2014/03/cara-penanggulangan-hama-dengan-bio.html (diunduh 10 April 2017)

http://megapolitan.kompas.com/read/2013/09/02/0820322/Berharap.Wajah.Jakarta.Lebih.Hijau (diunduh pada 14 April 2017)

http://www.belajarbarenghidroponik.com/2016/01/mengatasi-hama-semut-pada-tanaman.html (diunduh 17 april 2107)

http://hidrafarm.blogspot.co.id/2016/02/9-jenis-hama-tanaman-hidroponik-yang.html (diunduh 17 april 2017) 